\title{
Neither stable nor pristine: American bison populations were long influenced by humans
}

\author{
JAMES H. SHAW ${ }^{1 *}$ \\ ${ }^{1}$ Natural Resource Ecology and Management. Oklahoma State University. Stillwater, OK 74078. U.S.A. Email:jim.shaw@okstate.edu(JHS). \\ *Corresponding author
}

\begin{abstract}
Populations of North American bison (Bison bison) are widely presumed to have remained stable, numbering in the tens of millions, right up until the hide hunts of the 1870 s nearly brought about extinction. Recent scholarship from various disciplines consistently undermines this presumption. Indigenous people likely affected bison populations from their arrival toward the end of the Pleistocene. By the time of Columbus, indigenous populations were high and their impacts were felt keenly. As documented in the 16th century journals of Cabeza de Vaca, big game populations, including bison, were suppressed by hunting. That changed, however, with arrival of Old World diseases that are estimated to have reduced indigenous populations in the Americas by $90 \%$ within a century of contact with Europeans. Such drastic reductions in indigenous human populations allowed bison populations to expand. Gradually, increased pressure from human hunters, along with competition from feral horses, introduced infectious diseases, habitat changes, and droughts, all suppressed bison populations well before the notorious hide hunts began in the 1870s. The hide hunts were the final blow to free-ranging bison, but reduced populations in the decades prior paved the way and helps explain why bison were reduced to near extinction within a few years.
\end{abstract}

Se considera ampliamente que las poblaciones del bisonte Americano (Bison bison) se han mantenido estables, llegando a decenas de millones, hasta que la caza por sus cueros en la década de 1870 casi provocó la extinción. Estudios recientes de diversas disciplinas socavan consistentemente esta presunción. Los pueblos indígenas probablemente afectaron a las poblaciones de bisontes desde su llegada hacia el final del Pleistoceno. En la época de Colón, la población indígena era alta y sus impactos se sintieron profundamente. Como se documenta en el diario de Cabeza de Vaca del siglo XVI, las poblaciones de grandes mamíferos, incluido el bisonte, fueron disminuidas por su caza. Sin embargo, eso cambió con la llegada de enfermedades del Viejo Mundo, las que reducieron a las poblaciones indígenas en las Américas estimadamente un $90 \%$, en un siglo de contacto con los europeos. Tales reducciones drásticas en las poblaciones de los pueblos americanos permitieron que las poblaciones de bisontes se expandieran. Gradualmente, el aumento de la presión de los cazadores humanos, junto con la competencia de los caballos salvajes, introdujo enfermedades infecciosas, cambios de hábitat y sequías. Todo ello suprimió a las poblaciones de bisontes mucho antes de que comenzaran las notorias cacerías de pieles en la década de 1870. La caza de cueros fue el golpe final para los bisontes en libertad, pero la reducción de las poblaciones en las décadas anteriores allanó el camino y ayuda a explicar por qué los bisontes se redujeron a casi a la extinción en unos pocos años.

Keywords: Bison; hunting; indigenous; populations.

(c) 2021 Asociación Mexicana de Mastozoología, www.mastozoologiamexicana.org

\section{Introduction}

"It ain't what you don't know that gets you in trouble. It's what you know for sure that just ain't so." - Anonymous

The story of the American bison is well known, particularly as a case study on the need for conservation. In its most popular version, it goes something like this: American bison thrived for millennia in North America, in numbers of 60 million or more. American Indians hunted bison for their meat and skins in the late Pleistocene and throughout the Holocene. But Indians were always few in number and, being ecologically sensitive, took only what they needed, thus having a negligible impact on bison populations. It was only with the arrival of the hide hunters in the 1870s that the human impact was finally felt, resulting in a sudden crash in bison populations in the span of a few years, nearly causing extinction.

Historians and biologists have evaluated evidence of human impacts on North America's bison population. In doing so, they have challenged many popular elements of the bison story. Humans have affected bison populations for millennia primarily through hunting, although other forces of human origin were being introduced by the early $19^{\text {th }}$ century. Hunting impacted bison demographically, through reductions in numbers or skewing of sex ratios, and indirectly by concentrating bison in areas in which they were relatively safe. Similarly human hunting pressure excluded bison from areas in which they were particularly vulnerable to hunters.

Bison entered North America during the Pleistocene and underwent rapid and extensive speciation into at least four species: (Bison alaskensis, B. priscus, B. latifrons, and B. antiquus; McDonald 1981). Near the end of the Pleistocene, human hunters invaded North America, and some 35 genera of large mammals became extinct. Using improved dating techniques for fossils, Martin (1966) concluded that human hunters had caused these extinctions. Similar patterns of megafaunal extinctions following invasions of human hunters have been documented for Australia (Van Der Kaars et al. 2017), Madagascar (Martin 1966), and New Zealand (Perry et al. 2014).

Martin's "overkill" hypothesis has been challenged over the years by researchers who favor climate change at the 
end of the Pleistocene as the primary cause for the megafauna extinctions. Yet climate change was not concurrent with extinctions in Madagascar, Australia, and New Zealand. A thorough and detailed review of the controversy for the Americas (Haynes 2007) firmly concluded that overkill was the major force for megafauna extinctions.

Although bison survived the late Pleistocene, they became notably smaller in size during the last few millennia of the Holocene. This "Holocene dwarfing" made the extant bison of North America a newly evolved species (McDonald 1981). Human hunting pressure was likely a significant force behind the dwarfing, as smaller bison would reach reproductive age earlier than larger ones, and thus provide a demographic advantage in the face of higher mortality.

The journey of Cabeza De Vaca. In 1528, Spain sent the Panfilo de Narvaez expedition to Florida with the objective of establishing a Spanish colony. The expedition, consisting of five ships and 600 people, failed miserably. The second in command, Alvaro Nuñez Cabeza de Vaca and three other men were the lone survivors who, over the course of eight years, finally made their way to Mexico City (De Vaca 1542). After landing near present-day Tampa, the expedition marched into central Florida, then north and west to Florida panhandle. From there they traveled in barges along the Gulf coast from Florida to coastal Louisiana. After spending six years as captives among Indians on Last Island, De Vaca and his companions escaped to the mainland and traveled through southwestern Louisiana then through central Texas, New Mexico, and southeastern Arizona before turning south toward México City.

Although the expedition failed, the long journey of De Vaca provided perhaps the best insight into conditions in the continental United States prior to settlement by Europeans. The journey occurred before the onslaught of European diseases that over the next three centuries would kill millions of American Indians. Moreover, De Vaca was a Spanish nobleman, and like others of that time, was well acquainted with two pastimes: big game hunting and falconry, activities that fostered interest in and knowledge of wildlife (Geist 2018). Most importantly, upon returning to Spain, De Vaca published a long and detailed account of his experiences.

Geist (2018) reviewed the journals written by De Vaca (De Vaca 1542) using his accounts to test the notion that North America before European settlement was, as popularly believed, pristine, with few Indians and exceptionally abundant wildlife, particularly big game. What he found directly contradicted the popular view. Instead, throughout his journeys from Florida to Arizona and south into México, De Vaca reported abundant Indians and wildlife that was either absent or quite rare. Moreover, the Indians themselves lived on the edge of starvation. Some grew crops of maize, beans, or squash and hunted opportunistically. Others subsisted for months at a time on insects, snakes, lizards, rabbits, and even fruit of prickly pear (Opuntia spp.).
Throughout their travels, De Vaca and his men likewise suffered from insufficient food that, combined with inadequate clothing and shelter, resulting in much suffering and death. But what Geist (2018) found particularly striking was hardly any mention whatsoever of what later were common large species of wildlife, including wild turkeys (Meleagris gallopavo), American alligator (Alligator mississippiensis), American elk (Cervus elaphus), and pronghorn (Antilocapra americana). The only species of big game that was regularly mentioned was white-tailed deer (Odocoileus virginianus) that were scarce most places and abundant in only a few. Finally, passenger pigeons (Ectopistes migratorius), a species that would darken the skies of $19^{\text {th }}$ century America, were never mentioned at all.

De Vaca did observe live bison, but only three times, all apparently in southern or southwestern Louisiana (De Vaca 1542). Describing them as "cows", he noted that they were about the size of Spanish cattle and reported that he had eaten their meat. Farther west, he and his companions, based on their communications with various Indian groups, thought that bison were more common to the north of their route and encountered bison skins and robes that had arrived apparently along trade routes. Descriptions of bison by two of De Vaca's companions gave the distinct impression that they had not observed bison either frequently or at close quarters. One of them described bison as a "tapir" while the other thought that bison had a single horn emerging from their foreheads, unicorn-style (Guengerich 2013).

Although De Vaca's route was south of what in the $19^{\text {th }}$ century would be the heart of bison country, it would nonetheless have passed through the southern edge of the primary bison range as defined by McDonald (1981:104, fig 23). Thus, it seems safe to conclude that bison, like most other larger species of wildlife, were scarce. Given the large numbers of Indians encountered, and their constant quest for food, it also seems reasonable to conclude that bison were likely considerably less abundant in $16^{\text {th }}$ century America than in $19^{\text {th }}$ century America.

The "great dying". Geist's (2018) conclusions from analyzing the journals of Cabeza De Vaca were bolstered by a thorough and detailed analysis (Koch et al. 2019) that linked marked declines in populations of American Indians with ecological succession following abandonment of intensively used lands, a process that removed enough carbon dioxide from the atmosphere to trigger the "Little Ice Age". The authors first estimated the indigenous population of the Americas at the time Columbus first landed. They then evaluated the impacts of that population's land use. Next, they calculated the reductions in Indian populations from $1,500 \mathrm{CE}$ through $1,600 \mathrm{CE}$, roughly the first century following Columbus' voyage. Finally, they estimated the recovery of indigenous agricultural sites following the population decline in terms of carbon sequestration to infer effects that those changes would have had on climate. 
Koch et al. (2019) compiled estimates from extensive interdisciplinary literature reviews, cross-combined and sampled them using two different statistical methods, breaking down estimates for each of seven regions. Their model concluded that the mid-point for the pre-Columbia's population of the Americas was about 60.5 million and that the total land use area required to sustain them was roughly 61.9 million ha. A century later, the population of indigenous people had dropped by $90 \%$ to an estimated 6.1 million and the land use area proportionally declined to 6.1 million ha. As the estimated 55.8 million ha of abandoned cropland reverted primarily to forests, carbon dioxide was removed from the atmosphere.

These changes were deemed sufficient to trigger the Little Ice Age, beginning about 1610 when atmospheric carbon dioxide dropped to $272 \mathrm{ppm}$ (Koch et al. 2019). In terms of bison and other American wildlife, the $90 \%$ reduction in indigenous populations set the stage for the large populations recorded in the nearly three centuries following.

Bison population reductions prior to the hide hunts. Most of the actual observations of free-living North American bison are from the $19^{\text {th }}$ century, from the time of Lewis and Clark in the century's first decade to the commercial extinction of the northern herd in the early 1880s. Bison specialists have tried to estimate population sizes from historical accounts by three methods: estimates of herd sizes, estimates of numbers killed, and estimates of carrying capacity, and none of them generate reliable numbers (Shaw 1995).

One the most commonly cited estimate for $19^{\text {th }}$ century bison numbers was 60 million from Seton (1929). That number began with the observation of a single herd in 1871, which, taken at face value, would have contained 12 to 18 million bison. It was arbitrarily altered by Hornaday (1889) to four million perhaps to bring it in line with Hornaday's own estimates based on hide shipping records by one of three railroads (Roe 1970). An arbitrary assumption, likely a guess, was then made by Seton (1929) of the area required for a herd of that adjusted size, and the results projected on to the range map for North America (Roe 1970; Shaw 1995).

In more recent years, historians have favored estimates based on carrying capacity (Flores 2001; West 1995). Although these estimates may seem more "scientific", they are nonetheless seriously flawed. For one thing, carrying capacity is based upon the amount of forage required to sustain a population. Given the heavy human impact of hunting for subsistence and for market as well as the potential impacts of infectious diseases, droughts, and habitat alterations, it seems reasonable to infer that at least some bison populations of the $19^{\text {th }}$ century were held at levels below carrying capacity.

Even the estimates for carrying capacity themselves contain serious flaws. They were based upon a United States Department of Agriculture report published in 1910 that tallied 24 million horses and cattle plus 6 million sheep over an area of roughly half the bison range on the Great
Plains (Seton 1929). Indian-set fires were common on the Great Plains when bison were free-ranging. Moreover, free-ranging bison practiced short-term intensive grazing, rather than the more common continuous grazing of livestock whose movements by 1910 were restricted by fencing. Estimates of carrying capacity based on continuous grazing with fire suppression simply cannot be converted into reliable estimates of carrying capacity for free-ranging bison in frequently burned grasslands. Because of the limitations of historical estimates of bison population sizes, assessment of population reductions in the $19^{\text {th }}$ century in this paper are based upon range contractions, relative abundance, declines in bison robes traded, and accounts of serious food shortages by plains Indian tribes.

Predating the hide hunts of the 1870 s by decades, the robe trade was a force with the potential to suppress bison herds. For one thing, harvest was restricted to females, given their lighter and more pliable skins. For another, the demand was high and rose steadily. Declines in the robe trade in the face of high demand provided evidence of declines in bison at least in some regions.

Isenberg (2000) compiled records of bison robes traded. Between 1825 and 1830, fur traders shipped a total of 785,000 robes through New Orleans. By the 1840 s, western plains nomadic tribes brought more than 100,000 robes annually to steamboats for shipment east. The American Fur Company shipped 45,000 robes to Saint Louis in 1839. By 1847 , the number had risen to 110,000 . Shipping records showed a marked decline in the 1850s, likely reflecting reduced bison populations. The Upper Missouri Outfit of the American Fur Company shipped 89,000 robes in 1853, 75,000 in 1857, and 50,000 in 1859 (Isenberg 2000). Fort Pierre tallied 75,000 robes in 1849 , but by 1857 shipped only 19,000 (Isenberg 2000).

The robe trade's dependence upon female bison skewed the sex ratios of herds toward more males, thereby depressing calf production. In his classic work, "The Oregon Trail", Francis Parkman wrote of his observations in 1846, "Thousands of (bull bison) might be slaughtered without causing any detriment to the species, for their numbers greatly exceed those of the cows; it is the hides of the latter alone which are used for the purposes of commerce and for making the lodges of the Indians; and the destruction among them is therefore greatly disproportionate" (Parkman 1945:294). Those same steamboats that carried bison robes eastward along rivers imposed significant changes to riparian habitats as they were deforested to provide wood for fuel (Isenberg 2000). In addition, livestock pulling wagon trains of settlers along those same rivers consumed grasses in areas vital to bison in winter (West 1995).

Anthrax (Bacillus anthracis) struck bison populations particularly hard beginning in about 1800, though its effects were restricted to Canada and there is no evidence that it occurred south of the Canadian border (Isenberg 2000). Bovine tuberculosis (Mycobacterium bovis) probably was brought to bison by infected cattle from Texas. Brucellosis 
(Brucella abortus), although a controversy for the management of the Yellowstone bison in the $20^{\text {th }}$ century, probably arrived too late to impact $19^{\text {th }}$ century bison populations (Flores 2001). Drought struck the Great Plains starting in 1846 and lasted for a decade (Isenberg 2000). Its end coincided with the conclusion of the Little Ice Age (West 1995). The Little Ice Age ended after atmospheric carbon dioxide increased through deforestation and the burning of fossil fuels during the industrial revolution. Bryson (1974) estimated that in the decades following the end of the Little Ice Age, the changes would have reduced bison populations on the Great Plains by 50 to $75 \%$. Both the shortterm drought and the end of the Little Ice Age would have reduced forage production on the Great Plains and lowered the carrying capacity for bison.

Spatial distribution of bison in the $19^{\text {th }}$ century was influenced by conflicts between warring tribes that left buffer zones. Lewis and Clark found that a sparsely inhabited region of about 120,000 square $\mathrm{km}$ along the upper Missouri River contained an abundance of big game, including bison, elk, deer, and pronghorn. Clark realized that the game abundance was due to the buffer zone (Martin and Szuter 1999). Decades later, other buffer zones in Kansas and Colorado provided safe havens for bison. These buffer zones collapsed after peace was made in 1840 between the Comanches and Kiowas with their former enemies, the Cheyenne and Arapahos (Flores 2001). When the buffer zones disappeared, so did the bison (West 1995).

Thus, several significant forces-the robe trade, habitat alterations along rivers, introduction of infectious diseases, and loss of buffer zones-all began in the first half of the $19^{\text {th }}$ century, suppressing bison populations from earlier levels and destabilizing conditions on the Great Plains. In the absence of reliable estimates of actual bison numbers, reductions in bison abundance can be inferred through range contractions and through reports of starvation and hardship among plains Indians who relied upon bison for subsistence and trade. Range contraction began first in the western (shortgrass prairie) portions of the southern plains between 1821 and 1833 (Shaw and Lee 1997). By 1857, bison were displaced first from the west to about $240 \mathrm{~km}$ east of the Rocky Mountains (West 1995). This happened in a region still dominated by Indian hunters, not by white hunters who had long been presumed to be the cause (West 1995).

To the east in the tallgrass prairie regions, bison were displaced during the period 1833 to 1849 (Shaw and Lee 1997), although in that case the relative role of Indian vs white hunters is less clear. The forced transfer of Indian tribes from the southeast into Oklahoma Territory no doubt added to the pressure that displaced bison from tallgrass prairie regions (Flores 2001). By about 1850, Comanche were reported to be eating their horses and increasing their raids into Mexico, both signs of depleted bison. For four consecutive years, $1849,1850,1851$, and 1852, the Kiowa and Comanche hunting grounds contained few if any bison (Flores 2001).
The hide hunts. The hide hunts began suddenly following the 1871 development of a field technique to preserve bison hides using arsenic (Martin 1973). The industrial revolution created enormous demand for bison hides for use as belts in large machinery, and the hide hunts were on. By then breach-loading rifles had replaced muzzleloaders, enabling more firepower and greater ranges than ever before. The southern herd was essentially gone by late 1875 and the northern herd by about 1882 (McHugh 1972). Although there is no doubt that the hide hunts finished off free-living bison in North America, the impacts by humans earlier in the $19^{\text {th }}$ century reduced the populations to a significant extent, and made it easier for hide hunts to finish the job.

\section{Acknowledgments}

I wish to thank M. Meagher and V. Geist for their important insights and invaluable comments on an earlier version of this paper. Dedication for David James Schmidly: colleague, friend, mammalogist, and former president of three major universities. David always emphasized the impacts that people have had on populations of wild mammals, often in ways subtle but significant, and how they change over time.

\section{Literature cited}

Bryson, R. A. 1974. A perspective on climate change. Science 184:753-760.

De VACA, A. N. C. 1542. The journey of Alva Nunez Cabeza de Vaca. Translated by F. Bandolier, 1905.

FLORES, D. 2001. The natural west: Environmental history in the Great Plains and Rocky Mountains. University of Oklahoma Press. Norman, U.S.A.

GeIST, V. 2018. Human use of wildlife and landscapes in precontact southern North America, as recorded by Alvar Nuñez Cabeza de Vaca, 1527-1536. Beitrage Zurich Jody-und Wildforsohung, Bd. 43:397-406.

Guengerich, S. V. 2013. The perceptions of the bison in the chronicles of the Spanish northern frontier. Journal of the Southwest 55:251-276.

Haynes, G. 2007. A review of the attacks on the overkill hypothesis, with special attention to misrepresentation and double talk. Quaternary International 69-170:84-94.

HornadaY, W. T. 1889. The extermination of the American bison with a sketch of its discovery and life history. Smithsonian Report, 1887. Washington, U.S.A.

IsenBerG, A. C. 2000. The destruction of the bison: An environmental history. Cambridge University Press. Cambridge, U.S.A.

Koch, A., C. Briefly, M. M. Marlin, And S. L. Lewis. 2019. Earth system impacts of the European arrival and the great dying in the Americas after 1492. Quaternary Science Reviews 207:13-36.

Martin, C. 1973. The saga of the buffalo. Hart Publishing Co, Inc., New York, United States.

Martin, P. S. 1966. Africa and Pleistocene Overkill. Nature 212:339-342.

Martin, P. S., AND C. R. Szuter. 1999. War zones and game sinks in Lewis and Clark's west. Conservation Biology 13:36-45. 
McDonald, J. 1981. North American bison:Their classification and evolution. University of California Press. Berkeley, California, U.S.A.

McHugh, T. 1972. The time of the buffalo. Alfred A. Knopf, New York, U.S.A.

Parkman, F. 1945. The Oregon Trail. Doubleday, Doran and Company, Inc., Garden City, New York, U.S.A.

Perry, G. L. W., A. B. Wheeler, J. R. Wood, And J. M. Wilmshurst. 2014. A high precision chronology for the rapid extinction of New Zealand Mona (Aves, Dinornithiformes). Quarterly Science Reviews 202:126-135.

RoE, F. G. 1970. The North American Buffalo: A Critical Study of the Species in its Wild State (2nd edit). University Toronto Press. Toronto and Buffalo, United States.

Seton, E. T. 1929. Lives of game animals. 4 vols. Doubleday, Doran \& Co. Garden City, U.S.A.

SHAw, J. H. 1995. How many bison originally populated western rangelands? Rangelands 17:148-150.

Shaw, J. H., AND M. Lee. 1997. Relative abundance of bison, elk, and pronghorn on the southern plains, 1806-1857. Plains Anthropology 159:163-172.

Van Der KaArs, S., G. H. Muller, C. S. M. Tourney, E. J. Сook, D. Nurnberg, J. Schaenofelt, A. P. Keyshawn, and S. J. Lehman. 2017. Humans rather than climate change the primary causes of Pleistocene megafauna extinctions in Australia. Nature Communications 8:1-7.

West, E. 1995. The way to the west: Essays on the central plains. University of New Mexico Press. Albuquerque, U.S.A.

Associated editor: Lisa and Robert Bradley

Submitted: January 27, 2021; Reviewed: February 25, 2021;

Accepted:March 9, 2021; Published on line:May 28, 2021. 
176 THERYA Vol. 12(2): 171-175 